\title{
Participatory Landslide Inventory (PLI): An Online Tool for the Development of a Landslide Inventory
}

\author{
E. N. C. Perera $\mathbb{D}^{1},{ }^{1}$ A.M.C.T. Gunaratne $\mathbb{D}^{\circ},{ }^{2}$ and S.B.D. Samarasinghe $\mathbb{D}^{2}$ \\ ${ }^{1}$ Department of Regional Science and Planning, SANASA Campus, Kegalle, Sri Lanka \\ ${ }^{2}$ Higher Education Society Linkage Cell (HEI SL Cell), SANASA Campus, Kegalle, Sri Lanka \\ Correspondence should be addressed to E. N. C. Perera; chinssu@gmail.com
}

Received 3 November 2021; Revised 10 January 2022; Accepted 17 January 2022; Published 8 February 2022

Academic Editor: Nishant Malik

Copyright $(2022$ E. N. C. Perera et al. This is an open access article distributed under the Creative Commons Attribution License, which permits unrestricted use, distribution, and reproduction in any medium, provided the original work is properly cited.

A landslide inventory is a detailed register of the spatial distribution, geometry, and attributes of landslides and is essential for landslide hazard analysis, risk management, regional planning, and land use management and development, especially in landslide-prone regions. However, the development of a national landslide inventory is time-consuming and costly. Accordingly, most developing countries, including Sri Lanka, have basic landslide databases, which identify the location, date, and time of occurrence on a point map. This study, therefore, aimed to introduce a new method to report landslide information via a mobile application based on a participatory approach with information recorded in a web portal called the participatory landslide inventory (PLI). Twenty-one landslide site locations and their attributes were captured on the PLI web portal using the PLI mobile app. The system administrator then demarcated the landslide boundaries and performed geometrical calculations for each landslide to complete the inventory. Finally, the landslide information was published through the PLI web portal. The PLI is an effective and efficient tool for developing a landslide inventory economically.

\section{Introduction}

Landslides cause tens of billions of dollars worth of damage around the world every year, and losses are accelerating due to increased human activities, such as cultivation, construction, and development, on unstable slopes $[1,2]$. The National Building Research Organization (NBRO) has declared 14 districts, which constitute one-third of the land in Sri Lanka, as landslide vulnerable areas [3]. Studies conducted by the NBRO have revealed that nearly $70 \%$ of the landslides that occurred in populated areas in Sri Lanka are human-induced [4]. As a result, the frequency and severity of landslides in the country have increased in the recent past, which is in line with global trends [5-7]. Scientists therefore mostly focus on promoting landslide risk mitigation measures at local and global scales based on the available landslide information. Landslide inventories are the main source of landslide information used in landslide risk management.
A detailed and updated landslide inventory can be used to support susceptibility, hazards, and risk assessments because landslides are more likely to occur in areas that have previously experienced failure [8-12]. Landslide inventories are not only useful for risk analysis but also essential for regional planning and land use management and development, especially in landslide-prone areas $[8,13-15]$. A landslide inventory is a detailed register of the distribution and attributes of past landslides [13], so information on past landslides is best obtained through well-developed landslide inventories.

A landslide inventory should consist of two main components: a spatial component to show the location coordinates on the geometry (i.e., perimeter, area, and volume) and an attribute component, which includes the date of occurrence, type of failure, and damage caused $[8,16-20]$. In addition to this standard information, a landslide inventory may include the geology, geomorphology, damage, and costs incurred by the landslide depending 
on the purpose of the landslide inventory [21]. Structural information, available data, and database management systems of different types of landslide inventories are available across the world $[8,22]$.

Many developed countries have their own landslide inventories, which vary from basic paper maps to advanced automated geodatabases. The primary landslide inventory in Great Britain contains more than 17,000 landslide records [23], while Australia has several landslide inventories, which have been implemented by Geoscience Australia, the University of Wollongong, and Mineral Resources Tasmania [24]. The United States and Hong Kong use automated geodatabases for landslide inventory mapping $[2,25]$. Japan has developed event-based inventories after each landslide occurrence $[11,26]$. The upward trend in the frequency of landslides in developing countries demands new approaches to establish landslide inventories that can help improve disaster response and preparedness in the disaster management cycle [22]. A comprehensive landslide inventory not only helps improve risk management but also regional planning and land-use management decisions [27].

Landslide inventories have been developed using various methods. Conventional methods lead to the development of landslide inventories mainly based on the visual interpretation of satellite images, assisted by field surveys [28]. This kind of inventory is, however, time-consuming, and very costly in terms of data and workload. Today, the wide range of available Earth observation data facilitates the generation of web-based landslide inventory maps [8]. However, few countries have been developed freely accessible web-based landslide inventories such as Italy, Japan, and Switzerland. Some countries such as Java, Indonesia developed a participatory web-based landslide recording system [22]. Applying participatory webbased methods can contribute to more efficient monitoring and timesaving as well as cost-efficient development of a landslide inventory for a country $[22,28]$.

The existing landslide database in Sri Lanka includes only the locations of landslides on a point map, the date and time of their occurrence, and the impact of the landslides. This information is further limited to selected landslides. While this database focuses on recording information about landslides, it does not contribute to predisaster planning and preparedness. As a developing country, Sri Lanka needs a comprehensive landslide inventory that includes the capacity to support predisaster planning and preparedness, hazard assessment, disaster risk mitigation, risk management, and contingency planning [4].

This study aimed to introduce a new method to report landslide information using a mobile application based on a participatory approach and to record such information in a web portal called the participatory landslide inventory (PLI). As a sample inventory, a landslide inventory was developed using the PLI approach for selected landslides that have occurred in the Sabaragamuwa Province, Sri Lanka.

\section{Data Collection Area}

The Sabaragamuwa Province is located in the south-western region of the Central Highlands in Sri Lanka between a longitude of $80.1203^{\circ} \mathrm{E}$ and $80.56012^{\circ} \mathrm{E}$ and latitudes of $7.22028^{\circ} \mathrm{N}$ and $6.13059^{\circ} \mathrm{N}$ (Figure 1).

The Sabaragamuwa Province consists of two districts: Ratnapura and Kegalle. It covers an area of $4,968 \mathrm{~km}^{2}$ and has a population of two million inhabitants.

The province is hilly and mountainous with fractured and folded basement rocks overlaid by residual soil and colluviums [29]. As a result, high weathering and soil formation rates have created massive and thick unstable soil profiles, which are triggered by heavy rains. The Sabaragamuwa Province receives heavy rainfall mainly from the south-western monsoon from May to September and intermonsoon from October to November every year. The mean annual rainfall ranges from $2500 \mathrm{~mm}$ to $3000 \mathrm{~mm}$, and the average temperature is $25^{\circ} \mathrm{C}-30^{\circ} \mathrm{C}$ [30]. The elevation of the study area is $0-2177 \mathrm{~m}$ above the mean sea level. The province consists of 16 agro-ecological regions with wet, dry, and intermediate zones (Figure 1) and includes tropical rainforests, such as parts of Sinharaja and Sripada. Due to its geographical setting, geological formation, and climatic conditions, the Sabaragamuwa Province is considered a highly environmentally sensitive area and is particularly vulnerable to natural hazards, especially landslides and floods [31].

\section{Conceptual Model}

The PLI concept was initially proposed with the aim of developing a digital landslide inventory to fulfill the national demand for a landslide inventory in Sri Lanka rapidly and cost-effectively. The PLI mobile app reduces the cost of data gathering by allowing the community to take part in the data collection. The reported landslide data were submitted to the PLI web portal (https://www.pli-sanasacampus.com) by the data reporter. The received landslide data is then processed, manipulated, and enhanced using the tools available in the PLI web portal before being published via the same web portal by the system administrator (Figure 2). This mechanism adopted for the PLI system eliminates errors in the data reported by the public using their smart mobile devices. Furthermore, it only enables processed and confirmed data to be stored and published in the landslide inventory on the PLI web portal (Figure 2).

The mobile application of the PLI can be used to report landslide data from any part of the world. The PLI, therefore, has the potential to become a globally recognized system for the development of landslide inventories at regional and national levels. The primary aim behind the PLI concept is to develop a landslide inventory at a relatively low cost and within a minimal timeframe. The public has been provided with access to the PLI web portal because it requires data to be inputted by the community.

3.1. Functionality. In this study, landslide incidences in the Sabaragamuwa Province of Sri Lanka were added to a searchable, web-based map interface that can be used by researchers, planners, and the public. Although other webbased landslide inventories are available, the PLI is unique 


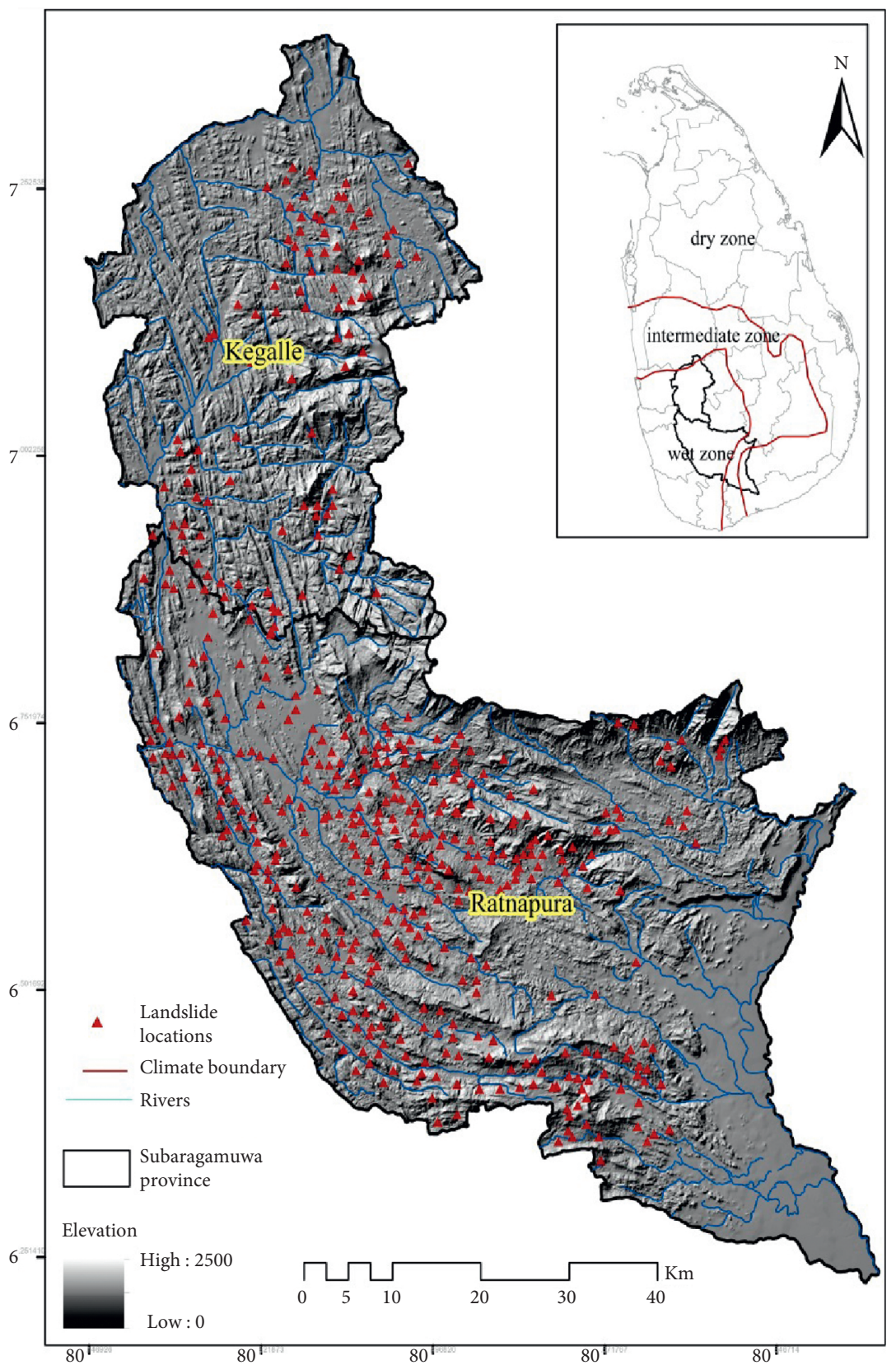

Figure 1: Geographical setting, landslide distribution, and elevation of the Sabaragamuwa.

because of its community-based data recording system $[9,32,33]$.

The PLI consists of two components. The first is the PLI mobile application, which enables the landslide location and attributes to be reported on the PLI web portal. The PLI mobile application is published on Google Play and can be installed on any smart mobile device. The interface with the PLI mobile application is shown in Figure 3. The user must first download and install the PLI mobile application from Google Play (https://play.google.com/store/apps/details? id=com.canopus.pli) on their smart mobile device (Figure 3(a)).

They then need to open the registration page because only registered users can report the landslide information and log into the system directly from the PLI web portal or via a Google, Facebook, or LinkedIn account (Figure 3(b)). After logging into the system, the data reporting interface appears (Figure 3(c)). This enables the user to input data related to a specific landslide into the system: the name of the village where the landslide occurred, the incident date and time, the current land cover, injuries, deaths, and damage to infrastructure (Figure 3(c)). To record the $x$ and $y$ coordinates of the location, the user must be in close proximity to the landslide because the system obtains the landslide coordinates via the Google Earth web-based program using the same smart mobile device. The user is not required to enter the attributes indicated on the reporting page (Figure 3(c)) as they can only send confirmed and available information to 


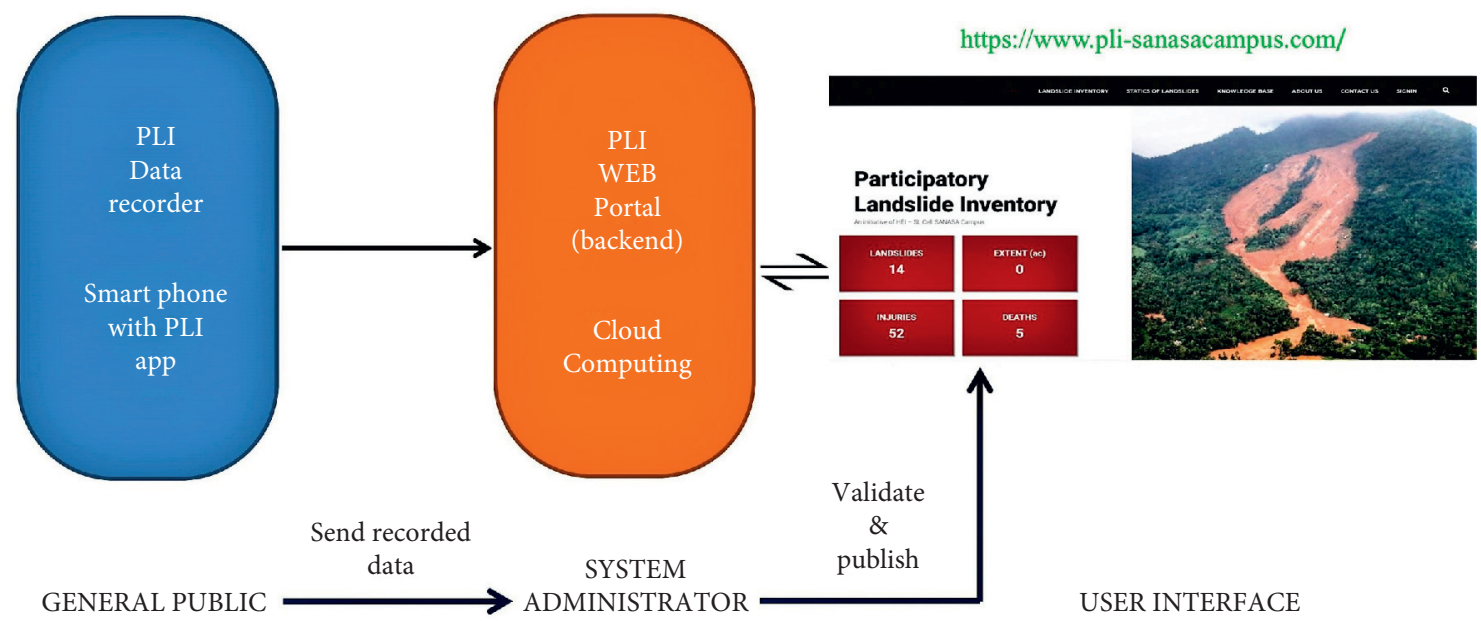

FIgURE 2: Simplified conceptual model of the participatory landslide inventory (PLI).

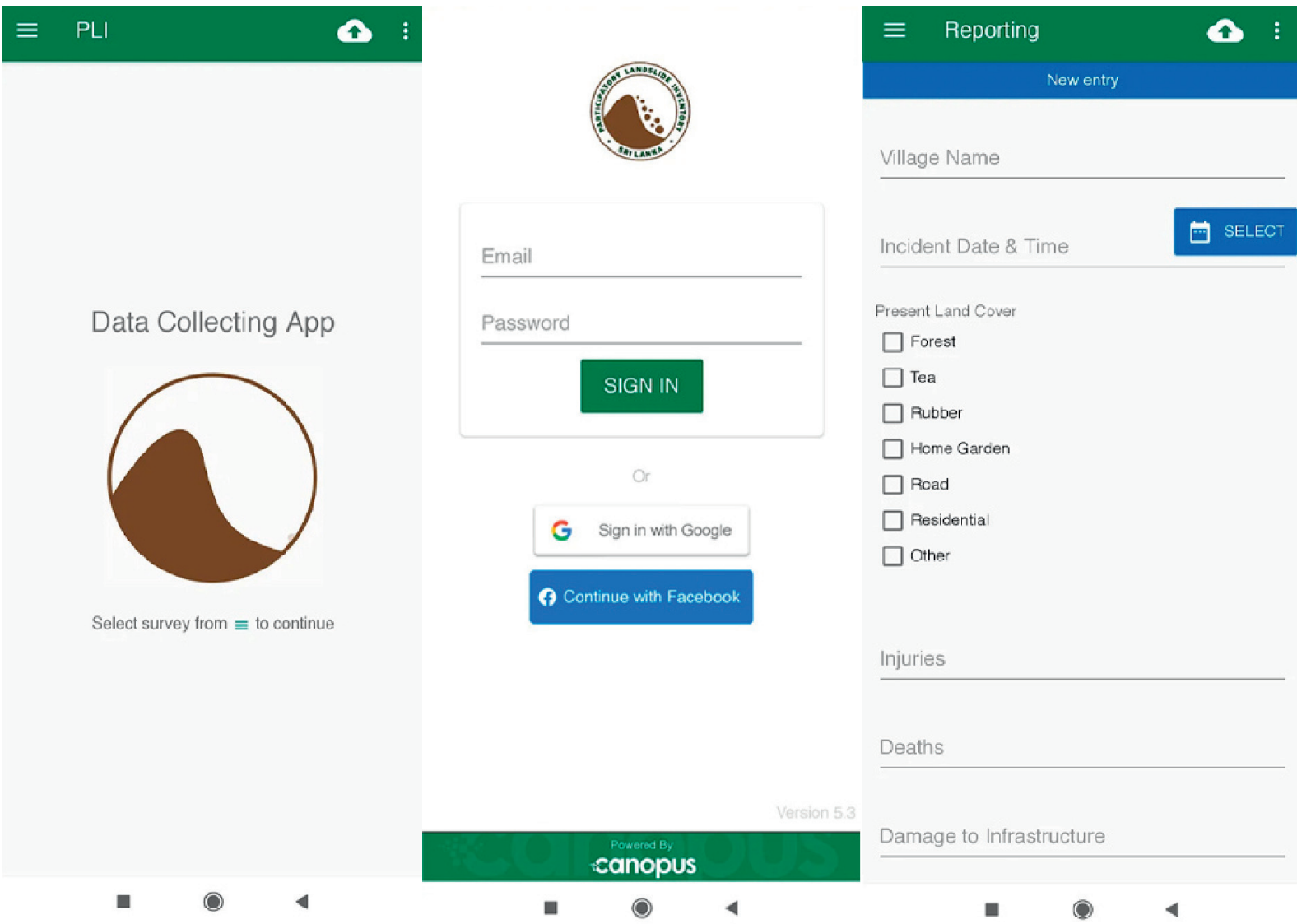

Figure 3: Interface of the PLI mobile application.

the web portal. The PLI mobile app can function offline, and users can report incidents from locations where the Internet connection is not available or very weak. Internet connection is only required to upload the information to the PLI web portal.

The second component of the PLI system is the web portal. When the location ( $x$ and $y$ coordinates) and attributes of a landslide are received by the PLI web portal, these data are transmitted to the PLI system administrator. The system administrator then processes and extracts the pertinent information and completes the mandatory information in the landslide inventory (Table 1). The shape of the landslide and its geometry are not included in the data packet sent by the PLI mobile app.

The PLI mobile app can only send the $x$ and $y$ coordinates of a given location in proximity to the landslide, but 
TABLE 1: Summary of fields included in the participatory landslide inventory.

\begin{tabular}{|c|c|c|}
\hline Main field & Sub filed & Description \\
\hline Event ID & $\begin{array}{c}\text { Province/District/No: Ex } \\
\text { SG/Ke/0001 }\end{array}$ & ID is provided using province code, district code, and number \\
\hline \multirow{6}{*}{ Location } & $\mathrm{X}-\mathrm{Y}$ coordinates & Location initially reported through PLI mobile app \\
\hline & Place name & Locally the place name \\
\hline & GND & Grama Niladhari division - obtained from GN map of SL \\
\hline & DSD & Divisional secretariats division - obtained from DSD map of SL \\
\hline & District & District - obtained from the district map of SL \\
\hline & Province & Province - obtained from the district map of SL \\
\hline Date & $\mathrm{DD} / \mathrm{MM} / \mathrm{YYY}$ format & Reported date, month, and year that the landslide event occurred \\
\hline \multirow[t]{2}{*}{ Time } & $\begin{array}{l}24 \text { hrs format } \\
\text { Length }\end{array}$ & Reported hour and minute of the failure \\
\hline & Area & \\
\hline \multirow[t]{4}{*}{ Geometry } & Depth & Manipulated using GIS software and the corresponding values are added* \\
\hline & $\begin{array}{l}\text { Flow direction } \\
\text { Volume }\end{array}$ & \\
\hline & Landslide & \\
\hline & Cutting failure & \\
\hline \multirow[t]{4}{*}{$\begin{array}{l}\text { Type of } \\
\text { landslide }\end{array}$} & $\begin{array}{l}\text { Slope failure } \\
\text { Rockfall } \\
\text { Creep }\end{array}$ & $\begin{array}{l}\text { Landslide types are included if known or specified in the source and include the most } \\
\text { frequently reported types of events: landslide, mudslide, debris flow, rockfall, creep, other, } \\
\text { or unknown** }\end{array}$ \\
\hline & Debris flow & \\
\hline & Unknown & \\
\hline & Active & Present moving \\
\hline \multirow{4}{*}{$\begin{array}{l}\text { Present } \\
\text { condition }\end{array}$} & Suspended & Moved within the last 12 months, but is not active at present \\
\hline & Dormant & Inactive landslide \\
\hline & Reactivated: & The active landslide which has been inactive \\
\hline & Stabilized & The inactive landslide which has been protected \\
\hline $\begin{array}{l}\text { Land use/ } \\
\text { cover }\end{array}$ & $\begin{array}{l}\text { Scarp } \\
\text { Body } \\
\text { Toe }\end{array}$ & Major plantations/forest and land use type \\
\hline \multirow{3}{*}{ Impact } & Injuries & Number of reported injuries as a result of the event \\
\hline & Deaths & Number of reported deaths as a result of the event \\
\hline & Damage to infrastructure & Number of reported damaged infrastructure \\
\hline
\end{tabular}

those coordinates can be used to locate the landslide site and visualize the landslide boundary using Google Earth. Landslides are identified from Google Earth images with the help of characteristics of sliding surfaces such as color, tone, surface roughness, and texture. These factors depend on the light reflected by the surface and can be used to infer rock, soil, and vegetation types, the latter being a proxy for wetness. The landslide boundary is easily recognizable immediately after a landslide event. Participatory landslide reporting approaches help locate landslides immediately after a landslide event. For recent landslides, the boundaries are usually distinct, making the identification and mapping of the landslide relatively easy. Therefore, the system administrator can then plot the boundary of the landslide polygon using the drawing tool available under the manage map menu on the left navigation bar of the PLI web portal (Figure 4).

By plotting the landslides as polygons, it is possible to add their perimeter, area, and direction to the landslide inventory. This polygon can be exported from Google Earth as a .kml file and converted into a shapefile (.shp) using GIS software to allow geometrical manipulation of the landslide to be performed. The system administrator can subsequently add the polygon of the boundary in . $\mathrm{kml}$ format as well as the geometry of the landslide to the corresponding fields in the landslide inventory system. Finally, the system administrator can publish the landslide inventory through the PLI web portal.

The content of a landslide inventory cannot be defined as it depends on the purpose of the inventory $[8,34]$. Table 1 uses the minimum requirement for a standard landslide inventory as described in the literature $[8,35]$. In the PLI system, the type of landslide is identified as a simplified version of the landslide classification [36]. Following this method, the system administrator can complete field 1 in Table 1 . They can then complete the landslide inventory by inputting the required socioeconomic information such as the impact obtained from the field visits and the District office of the Disaster Management Center (DMC) of Sri Lanka. However, to get the geometry of the landslide, Google Earth should update the satellite images of the area. To add the socioeconomic information, the DMC of Sri Lanka should publish the confirmed information. Therefore, to complete inventory for recently occurred landslide events, it 


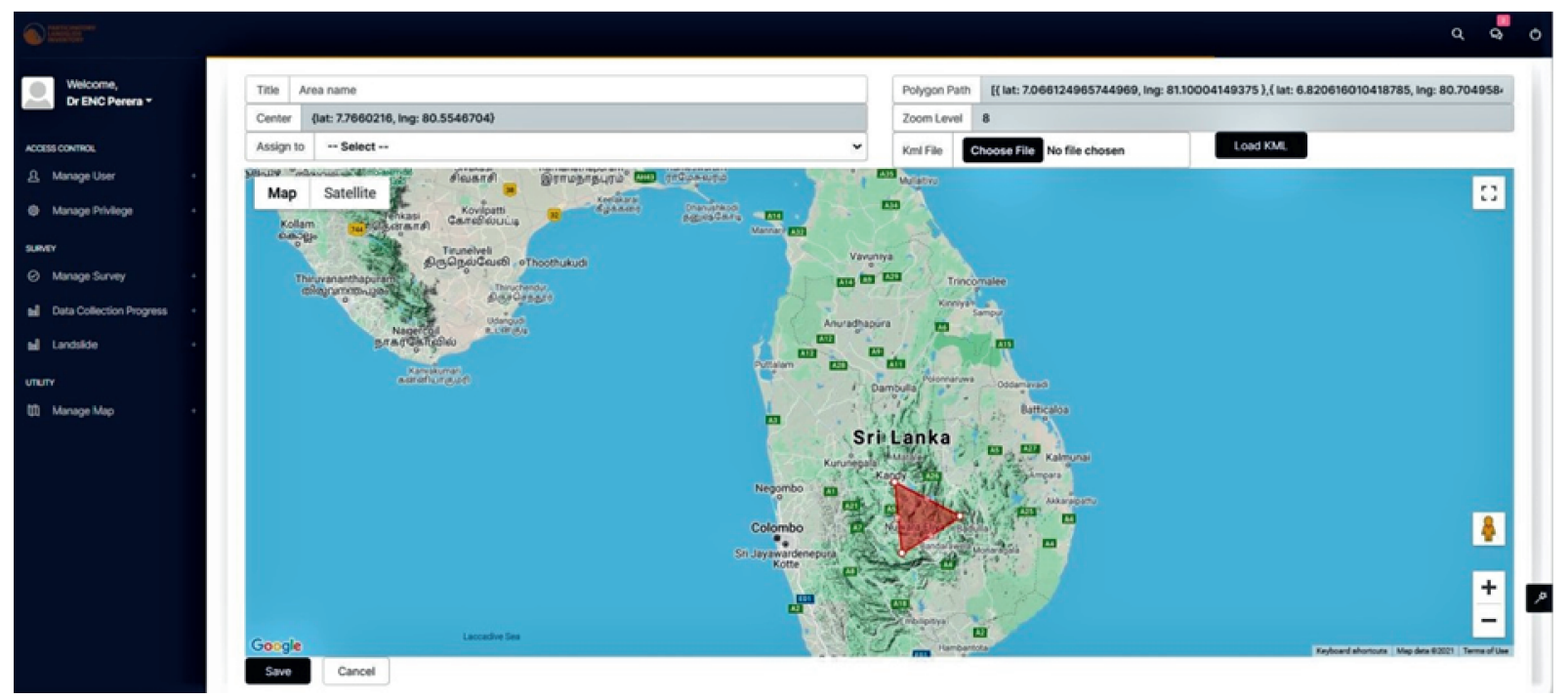

Figure 4: Adding spatial information to the inventory: landslide boundary demarcation tool in the PLI web portal.

will take nearly 2-3 months in Sri Lanka, but historic landslide events could be recorded in the PLI web portal within 24 hours due to the availability of satellite images and other socioeconomic information. The boundary of smallscale landslides could not be identified from Google Earth; therefore, it could be mapped using handheld GPS.

\section{Methodology: Development of the Landslide Inventory for the Sabaragamuwa Province}

The development of the landslide inventory requires the collection of the spatial (location of the landslide) and attributes data of landslides using the PLI mobile app. To pilot the PLI mobile application developed in this study, data were collected by four graduates hired as field enumerators. The training for the data collection protocol was conducted for all field enumerators over a two-day period from July 12021 to July 2, 2021, by the research team. The training consisted of a general orientation regarding the PLI mobile app, the spatial data recording system, the information recording method, and the standard care of the device. The training also included information on troubleshooting and how to deal with technical difficulties that might arise with mobile phones. A total of 21 landslide sites were selected, which included four in the Kegalle district and 17 in the Ratnapura district representing the Sabaragamuwa Province prior to the implementation of a field survey based on the landslide records of the NBRO Sri Lanka. During the field survey, the locations of the landslides were reported directly, and as far as possible, the landslide attributes were obtained from the surrounding communities. Although the location information was accurately recorded using the PLI mobile application, various contradictions were observed in the data obtained from the public. Unreliability is one of the major drawbacks of community-based data collection [37]. However, the interest and contribution showed by the community in providing past landslide data were observed by the enumerators.
The collected data were recorded as accurately as possible and sent to the system administrator via the PLI mobile app. If no mobile network coverage was available, the recorded information was stored securely until signal was found to upload the completed survey. During two weeks, 21 landslide incidents were recorded with no data loss. Quality checks were performed in real-time, and inconsistencies were detected, rectified, and cleaned in a timely manner by the system administrator with the support of the NBRO. Immediately following the completion of the attributed data clearance for each landslide, the location of the landslide was explored using Google Earth through the PLI web portal. When a landslide occurs, the surface morphology changes and leaves a distinct signature, and Google Earth can provide a clear boundary view of recent landslides [38]. If a landslide has a clear boundary, the boundary demarcation will be accurate [39]. In this study, however, all reported landslides occurred before 2018, so it was not possible to clearly demarcate their boundaries from current Google Earth images. To obtain a clear landslide boundary, historical satellite images captured close to the time of the landslide were explored using the "Show historical image" tool in Google Earth. The time slider bar in this tool facilitates navigation between images with different dates. After selecting the best satellite image of the landslide, the landslide was zoomed and rotated to visualize its features clearly. The landslide boundary was then demarcated using the drawing tool available in the PLI web portable, as shown in Figure 4. The demarcated landslide boundary was in .kml format, so it was converted into a shapefile using ArcGIS 10.3 to calculate the geometry (i.e., length, perimeter, volume, and depth). Finally, all geometrical information fields in the inventory for the 21 selected landslides were filled.

\section{Results and Discussion}

The developed PLI mobile application is a live system that is continually upgraded and updated with information of 


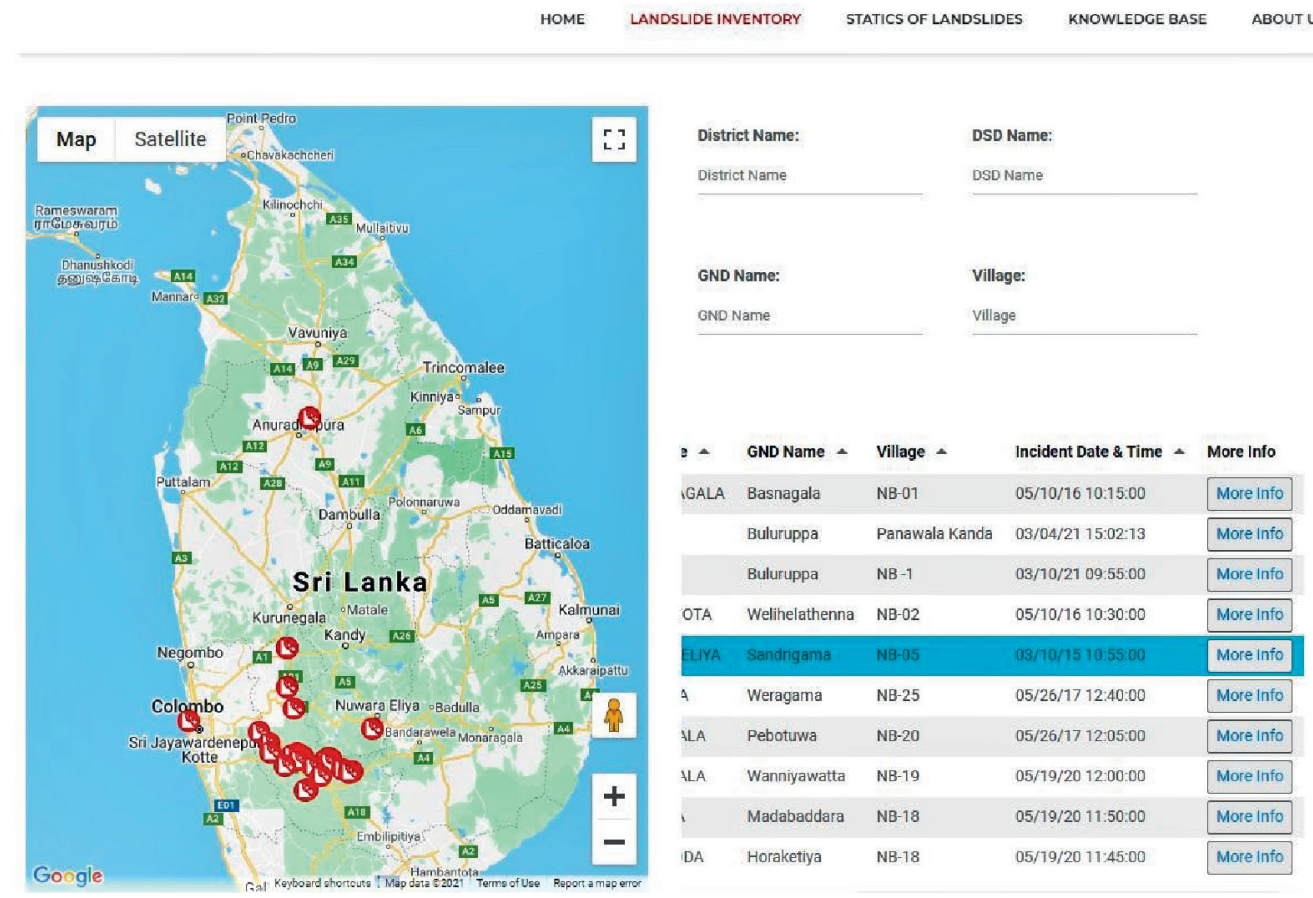

FIgURE 5: Landslide inventory in the PLI web portal.

landslides that have recently occurred. Complete information about the landslides can be obtained from the PLI web portal. The primary information about the landslides is summarized in a table on the inventory page of the PLI web portal (Figure 5). The spatial distribution of the recorded landslides is displayed in a map adjacent to the inventory database (Figure 5). Users can obtain the complete details of any landslide by clicking on the "More information" tab in the table or on the location on the map. The inventory enables users to query and filter the landslides' distribution spatially at DSD and GN levels.

The collected landslide information can be summarized in numerous ways to extract more information. The inventory enables the graphic representation of the landslide distribution district-wise in a bar chart (Figure 6(a)).

According to the district-wise distribution of landslides included to date, the highest number of landslides was recorded in the Ratnapura district. The inventory can also present the recorded number of deaths in the district (Figure 6(b)). At the time of writing, the Kegalle district had the highest number of death records, with 167 deaths due to the landslide that occurred in 2016 in Aranayaka. The recorded landslides can be classified according to their forming materials and type of movement (Figure 6). Of the recorded landslides, the majority (nine) were cut slope failures and occurred due to unplanned road construction in rural areas in the Sabaragamuwa Province. The PLI web portal can also provide statistics on the affected land use/ cover types by a landslide (Figure 6(d)).

A map of the landslide polygons can be extracted from the PLI web portal in a $\mathrm{kml}$ format. The polygon mapping of the landslides makes it possible to analyze their perimeter, area, volume, and flow direction. The maps of the six selected landslides obtained from the PLI web portal are shown in Figure 7.

The landslide polygons were superimposed onto a slope angle map, which demonstrated that many of the landslides occurred on gentle slopes (i.e., between $40^{\circ}$ and $60^{\circ}$ ). Similarly, the anatomy, flow direction, and land use classes under different parts of the landslide can be obtained from the landslide inventory maps in the PLI web portal. The PLI system is capable of recording and publishing any landslide in both Sri Lanka and the rest of the world.

Participatory landslide mapping enables local communities to interpret some aspects of their experience with local landslides. Local populations are most likely to know the precise locations and boundaries of past landslides because of that their motivation towards the data reporting is very essential. Therefore, to promote the recording of landslides through the PLI mobile application, it is necessary to conduct an outreach program using local community organizations. Local communities need to be convinced that this will create a more secure environment for the landslideprone areas. In addition, the information generated by PLI should be disseminated through community organizations to local people in order to plan their construction and plantation. Awareness of these types of benefits may motivate local communities to record data continuously to the PLI system.

In remote areas, landslides may not be reported to the system due to the lack of accessibility to the local communities. However, with the support of satellite images, it is possible to find the landslides that occurred in rural areas. But it will be a time-consuming method. 


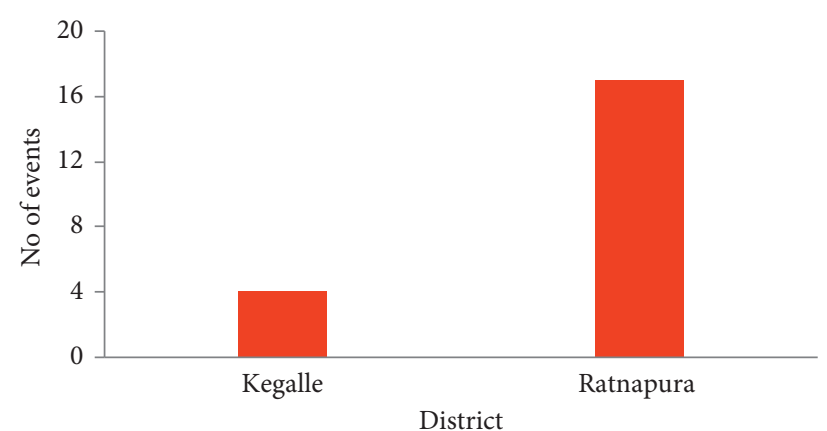

(a)

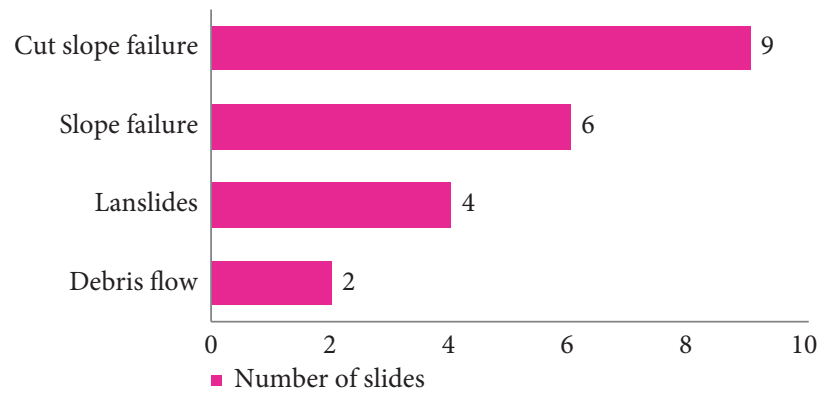

(c)

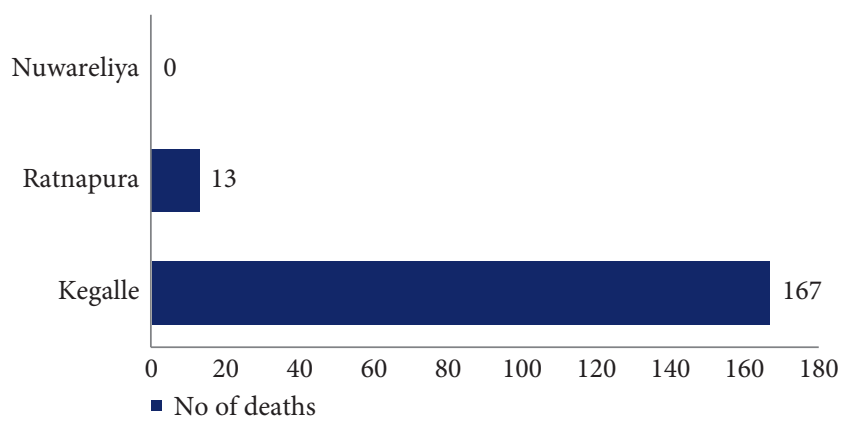

(b)

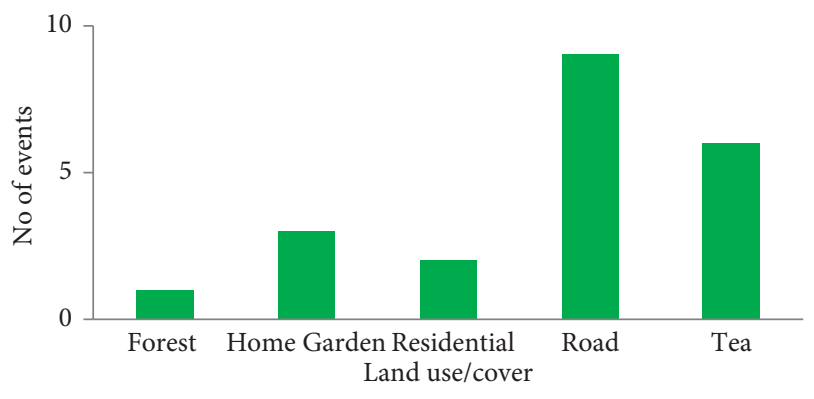

(d)

FIgURE 6: Statistics of landslide distribution in Sabaragamuwa province, Sri Lanka.
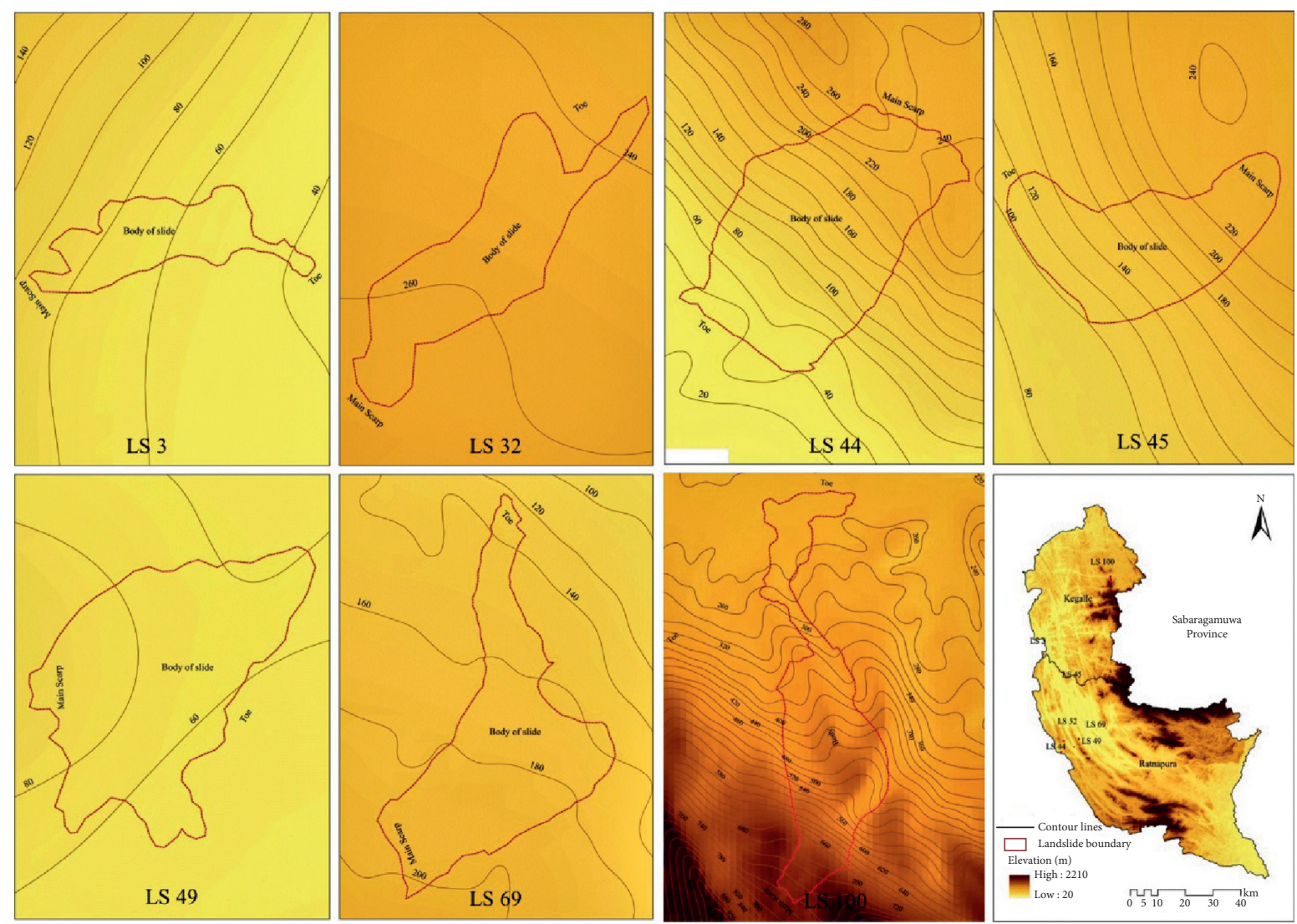

Figure 7: Map of a polygon of selected landslides extracted from the PLI web portal. 


\section{Conclusions and Recommendations}

The PLI system was developed to record landslide data using a participatory approach and to publish the data with enhanced information to the general public via a web portal. In this study, we combined the traditional method of fieldbased geomorphological surveys involving active participation from communities with the use of innovative technology to report landslide information. The PLI is a precise, cost-effective, and practical approach that can be used in developing countries to generate national landslide inventories. During the field visits undertaken during this study, it was noted that the involvement of the local people in mapping activities was generally high, and there was an active and enthusiastic engagement in providing information on past landslides. The PLI generates. $\mathrm{kml}$ files of landslide polygons, which enables the data to be captured in a GIS program for postprocessing. This helps improve the mapping activities and offers better information on landslides. Notwithstanding, drawing polygons of landslides on a screen is a time-consuming process. Furthermore, when reporting data relating to historical landslides, we observed a lack of accurate information regarding, for example, date and time, the number of affected people, land use, and material losses. Lastly, when postprocessing the data on the web portal, it was difficult to locate information on past landslides, even when using national databases. However, the PLI system is very efficient in recording and publishing information on recent landslides and can aid in the creation of standard landslide inventories for countries that do not currently have landslide inventories.

\section{Data Availability}

The data are available at www.pli-sanasacampus.com.

\section{Conflicts of Interest}

The authors declare that there are no conflicts of interest.

\section{Acknowledgments}

This research was supported by the Accelerating Higher Education Expansion and Development (AHEAD) Project Operation of the Ministry of Education funded by the World Bank.

\section{References}

[1] J. J. Clague and N. Roberts, "Landslide hazard and risk," in Landslides: Types Mechanisms and Modeling, J. J. Clague and D. Stead, Eds., pp. 1-9, Cambridge University Press, Cambridge, England, 1st edition, 2012.

[2] Q. Lin, Y. Wang, T. Liu, Y. Zhu, and Q. Sui, "The vulnerability of people to landslides: a case study on the relationship between the casualties and volume of landslides in China," International Journal of Environmental Research and Public Health, vol. 14, no. 2, pp. 212-226, 2017.

[3] B. W. G. I. D. Gunarathna, A. B. Jayasinghe, C. C. Abenayake, and P. K. S. Mahanama, "Assessing the impact of land use on triggering landslides: a case of Sabaragamuwa Province, Sri
Lanka," Bhumi, The Planning Research Journal, vol. 6, no. 2, pp. 15-28, 2018.

[4] R. M. S. Bandara and P. Jayasingha, "Landslide disaster risk reduction strategies and present achievements in Sri Lanka historical background of landslide research in Sri Lanka," Geoscience Research, vol. 3, pp. 21-27, 2018.

[5] E. N. C. Perera, D. T. Jayawardana, and P. Jayasinghe, "A rainfall intensity-duration threshold for mass movement in badulla, Sri Lanka," Journal of Geoscience and Environment Protection, vol. 05, no. 12, pp. 135-152, 2017.

[6] U. Ratnayake and S. Herath, "Changing rainfall and its impact on landslides in Sri Lanka," Journal of Mountain Science, vol. 2, no. 3, pp. 218-224, 2005.

[7] S. L. Gariano and F. Guzzetti, "Landslides in a changing climate," Earth-Science Reviews, vol. 162, pp. 227-252, 2016.

[8] F. Guzzetti, A. C. Mondini, M. Cardinali, F. Fiorucci, M. Santangelo, and K.-T. Chang, "Landslide inventory maps: new tools for an old problem," Earth-Science Reviews, vol. 112, no. 1-2, pp. 42-66, 2012.

[9] C. S. Juang, T. A. Stanley, and D. B. Kirschbaum, "Using citizen science to expand the global map of landslides: introducing the cooperative open online landslide repository (COOLR)," PLoS One, vol. 14, no. 7, Article ID e0218657, 2019.

[10] E. N. C. Perera, D. T. Jayawardana, M. Ranagalage, and P. Jayasinghe, "Spatial multi criteria evaluation (smce) model for landslide hazard zonation in tropical hilly environment : a case study from Kegalle," Geoinformatics \& Geostatistics: An Overview Research, vol. 1, 2018a.

[11] U. Ozturk, M. Pittore, R. Behling, S. Roessner, L. Andreani, and O. Korup, "How robust are landslide susceptibility estimates?” Landslides, vol. 18, no. 2, pp. 681-695, 2020.

[12] J. Samia, A. Temme, A. Bregt et al., "Do landslides follow landslides? Insights in path dependency from a multi-temporal landslide inventory," Landslides, vol. 14, no. 2, pp. 547-558, 2017.

[13] J. Hervás, "Landslide inventory," in Encyclopedia of Natural Hazards. Encyclopedia of Earth Sciences Series, P. T. Bobrowsky, Ed., Springer, Dordrecht, Netherlands, 2013.

[14] E. N. C. Perera, D. T. Jayawardana, M. Ranagalage, D. M. S. L. B. Dissanayake, and H. M. D. S. Wijenayaka, "Introduce a framework for landslide risk assessment using geospatial analysis: a case study from Kegalle District, Sri Lanka," Modeling Earth Systems and Environment, vol. 6, no. 4, pp. 2415-2431, 2020.

[15] C. Xu, "Preparation of earthquake-triggered landslide inventory maps using remote sensing and GIS technologies: principles and case studies," Geoscience Frontiers, vol. 6, no. 6, pp. 825-836, 2015.

[16] M. V. D. Eeckhaut and J. Hervás, "Landslide inventories in Europe and policy recommendations for their interoperability and harmonization A JRC contribution to the EU-FP7 Safe Land project," 2012.

[17] A. Rosi, V. Tofani, L. Tanteri et al., "The new landslide inventory of Tuscany (Italy) updated with PS-InSAR: geomorphological features and landslide distribution," Landslides, vol. 15, no. 1, pp. 5-19, 2018.

[18] R. Soeters and C. J. van Westen, "Slope instability recognition, analysis, and zonation," in Landslides Investigation and Mitigation, A. K. Turner and R. L. Schuster, Eds., pp. 129-177, National Academy Press, Washington, DC, 1996.

[19] G. F. Wieczorek, "Preparing a detailed landslide-inventory map for hazard evaluation and reduction," Environmental and Engineering Geoscience, vol. xxi, no. 3, pp. 337-342, 1984. 
[20] K. Rana, U. Ozturk, U. Ozturk, and N. Malik, "Landslide geometry reveals its trigger," Geophysical Research Letters, vol. 48, no. 4, 2021.

[21] R. Pellicani and G. Spilotro, "Evaluating the quality of landslide inventory maps: comparison between archive and surveyed inventories for the Daunia region (Apulia, Southern Italy)," Bulletin of Engineering Geology and the Environment, vol. 74, no. 2, pp. 357-367, 2014.

[22] G. Samodra, G. Chen, J. Sartohadi, and K. Kasama, "Generating landslide inventory by participatory mapping: an example in Purwosari Area, Yogyakarta, Java," Geomorphology, vol. 306, no. 4, pp. 306-313, 2018.

[23] C. Foster, C. V. L. Pennington, M. G. Culshaw, and K. Lawrie, "The national landslide database of Great Britain: development, evolution and applications," Environmental Earth Sciences, vol. 66, no. 3, pp. 941-953, 2012.

[24] C. Mazengarb, P. Flentje, A. Miner, and M. Osuchowski, "Designing a landslide database ; lessons from Australian examples. Geologically active," in Proceedings of the 11th IAEG Congress of the International Association of Engineering Geology and the Environment, Routledge, Auckland, New Zealand, 5 September 2010.

[25] F. C. Dai and C. F. Lee, "Landslide characteristics and slope instability modeling using GIS, Lantau Island, Hong Kong," Geomorphology, vol. 42, no. 3-4, pp. 213-228, 2002.

[26] S. Von Specht, U. Ozturk, G. Veh, F. Cotton, and O. Korup, "Effects of finite source rupture on landslide triggering: the 2016 Mw 7.1 Kumamoto earthquake," Solid Earth, vol. 10, no. 2, pp. 463-486, 2019.

[27] C. Del Ventisette, G. Righini, S. Moretti, and N. Casagli, "Multitemporal landslides inventory map updating using spaceborne SAR analysis," International Journal of Applied Earth Observation and Geoinformation, vol. 30, pp. 238-246, 2014.

[28] D. Hölbling, P. Füreder, F. Antolini, F. Cigna, N. Casagli, and S. Lang, "A semi-automated object-based approach for landslide detection validated by persistent scatterer interferometry measures and landslide inventories," Remote Sensing, vol. 4, no. 5, pp. 1310-1336, 2012.

[29] P. G. Cooray, "An introduction to the geology of Sri Lanka (ceylon)," Geological Magazine, Xiv, pp. 85-97, Cambridge University Press, Cambridge, England, 1984.

[30] A. L. K. Wijemannage, M. Ranagalage, and E. N. C. Perera, "Comparison of spatial interpolation methods for rainfall data over Sri Lanka," in Proceedings of the The proceedings of Asian conference in remote sensing, Asian association on remote sensing, Colombo, SriLanka, 17 October 2016.

[31] S. Senanayake, B. Pradhan, A. Huete, and J. Brennan, "Assessing soil erosion hazards using land-use change and landslide frequency ratio method: a case study of Sabaragamuwa province, Sri Lanka," Remote Sensing, vol. 12, no. 9, p. 1483,2020

[32] E. S. Jones, B. B. Mirus, R. G. Schmitt et al., Summary Metadata - Landslide Inventories across the United States: U.S, Geological Survey data release, U.S, 2019.

[33] Van Westen, "Caribbean handbook on risk management.ACP-EU natural disaster risk reduction programme," 2012, http://www.charim.net/.

[34] H. Tanyaş, C. J. van Westen, K. E. Allstadt et al., "Presentation and analysis of a worldwide database of earthquake-induced landslide inventories," Journal of Geophysical Research: Earth Surface, vol. 122, pp. 1991-2015, 2017.

[35] C. J. Van Westen, P. Jaiswal, S. Ghosh, T. R. Martha, and S. L. Kuriakose, "Landslide inventory, hazard and risk assessment in India," Terrigenous Mass Movements, vol. 12, pp. 239-282, 2012.

[36] D. M. Cruden and D. J. Varnes, "Landslide types and processes," in Landslides, Investigation and Mitigation, Special Report 247, A. K. Turner and R. L. Schuster, Eds., pp. 36-75, Transportation Research Board, Washington, US, 1996.

[37] M. Tomlinson, W. Solomon, Y. Singh et al., "The use of mobile phones as a data collection tool: a report from a household survey in South Africa," BMC Medical Informatics and Decision Making, vol. 9, no. 1, 2009.

[38] E. N. C. Perera, D. T. Jayawardana, P. Jayasinghe, R. M. S. Bandara, and N. Alahakoon, "Direct impacts of landslides on socio- economic systems: a case study from Aranayake, Sri Lanka," Geoenvironmental Disasters, vol. 5, pp. 45-57, 2018b.

[39] L. Guerriero, D. Di Martire, D. Calcaterra, and M. Francioni, "Digital image correlation of Google Earth images for earth's surface displacement estimation," Remote Sensing, vol. 12, no. 21, pp. 3518-3614, 2020. 